\title{
Ethylene Biosynthesis and Polyamine Accumulation in Apples with Watercore
}

\author{
Shiow Y. Wang and Miklos Faust \\ Department of Agriculture, Beltsville, MD 20705 \\ Additional index words. Malus domestics, physiological disorder, postharvest physiology
}

Fruit Laboratory, Beltsville Agricultural Research Center Agricultural Research Service, U.S.

Abstract. Ethylene biosynthesis and polyamine content were determined in normal and watercore-affected apple (Malus domestics Borkh. Cv. Delicious). Fruit with watercore produced more ethylene and contained higher amounts of putrescine (PUT), spermidine (SPD), 1-aminocyclopropane-1-carboxylic acid (ACC), and 1-(malonylamino) cyclopropane-1-carboxylic acid (MACC). The activities of ACC synthase and ethylene-forming enzyme (EFE) in watercoreaffected fruit were also higher than in normal fruit. The EFE activity in severely affected flesh was inhibited, resulting in ACC accumulation and low ethylene production. S-adenosylmethionine (AdoMet) was maintained at a steady-state level even when $\mathrm{C}_{2} \mathrm{H}_{4}$ and polyamides were actively synthesized in normal and affected fruit.

Watercore is a disorder that is usually associated with vascular bundles in apple fruit. Therefore, sorbitol, the major translocating carbohydrate in apple, cannot enter the cells; it remains in the intercellular spaces, where the higher osmoticum promotes water retention (Marlow and Loescher, 1984; Williams, 1966). As a consequence, the disorder appears as a translucent watersoaked area. In severe cases, the pitch adjacent to the core and all of the cortex may also be affected (Fisher, 1923; Marlow and Loescher, 1984; Olsen et al., 1962; Williams, 1966). The afflicted tissues have an elevated water content, decreased levels of reducing sugars and pectin, increased anaerobic products, and a higher sorbitol content (Atkinson, 1971; Faust et al., 1969; Marlow and Loescher, 1984; Williams, 1966) than normal tissue. Watercore may disappear after harvest if the symptoms are mild. However, a severe form of the disorder may cause internal breakdown during storage (Marlow and Loescher, 1984) and may result in severe economic losses.

Watercore usually occurs at an advanced stage of maturity. Kato and Sato (1978) found that affected apples had a higher concentration of internal $\mathrm{C}_{2} \mathrm{H}_{4}$ and higher rate of $\mathrm{C}_{2} \mathrm{H}_{4}$ evolution in whole fruit than unaffected fruit. The high $\mathrm{C}_{2} \mathrm{H}_{4}$ content in the watercore-affected fruit could be a result of stress caused by high sorbitol concentration. Osmotic stress caused by a high concentration of sorbitol has been found to enhance polyamine levels (Flores and Galston, 1984). Ethylene and polyamine biosynthesis use the same substrate, AdoMet, and produce the same by-product, methylthioadenosine (Adams and Yang, 1977). In general, $\mathrm{C}_{2} \mathrm{H}_{4}$ has multiple effects associated with senescence; it initiates fruit ripening, induces chlorophyll loss in leaves, and promotes senescence (Yang and Hoffman, 1984). On the contrary, polyamides are senescence inhibitors. They inhibit the rise in RNase (EC 3.1.27.5), protease (EC 3.4.24.4), and peroxidase (EC 1.11.1.7); reduce the rate of senescence of leaf protoplasts; induce DNA synthesis and mitotic activity; promote the synthesis of macromolecules; stabilize thylakoid membranes; maintain high protein content; and prevent the loss of chlorophyll in leaf disks (Galston, 1983). Since $\mathrm{C}_{2} \mathrm{H}_{4}$ and polyamides have opposing effects, the purpose of this study was to investigate the relation of these two types of compounds in

\footnotetext{
Received for publication 6 May 1991. Accepted for publication 15 Aug. 1991. Use of a company or product name does not constitute an endorsement by the U.S. Dept. of Agriculture nor imply approval to the exclusion of other suitable products. The cost of publishing this paper was defrayed in part by the payment of page charges. Under postal regulations, this paper therefore must be hereby marked advertisement solely to indicate this fact.
}

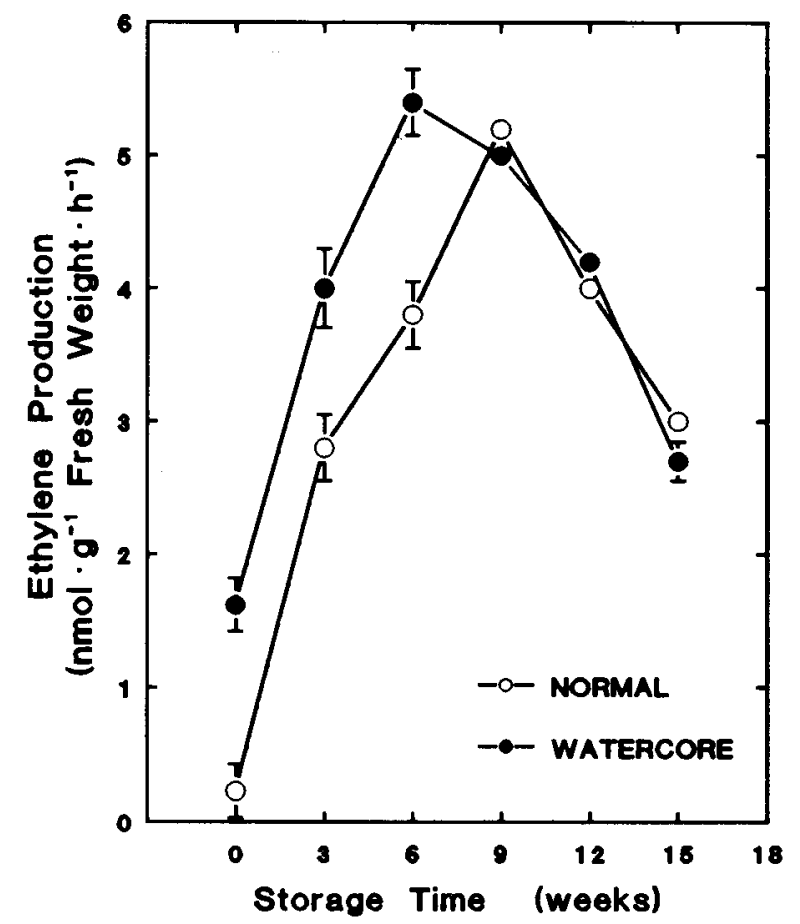

Fig. 1. Ethylene production by intact normal and watercore-affected 'Delicious' apples before storage and periodically after removal from $0 \mathrm{C}$ storage and warming to $20 \mathrm{C}$ for assay. Vertical bars denote $\pm \mathrm{SE}$, bars smaller than the symbols are not shown.

watercored tissues to increase our understanding of this important disorder in apple fruit.

\section{Materials and Methods}

Plant material. 'Delicious' apples were harvested from ten 8-year-old apple trees in an orchard at Beltsville, Md., and stored in $0 \mathrm{C}$ air. The diameters of the fruit ranged from 6.5 to $7.5 \mathrm{~cm}$. Nuclear Magnetic Imaging (NMI) was used to determine the severity of watercore and to group the apples into various classes (Wang et al., 1988). Whole apples and tissue

\footnotetext{
Abbreviations: ACC, 1-aminocyclopropane-1-carboxylic acid; AdoMet, S-adenosylmethionine; DTE, dithioerythritol; EFE, ethylene-forming enzyme; FID$\mathrm{GC}$, flame ionization detector-gas chromatography; MACC, 1-(malonylamino) cyclopropane-1-carboxylic acid; PUT, putrescine; SPD, spermidine; SPM, spermine.
} 


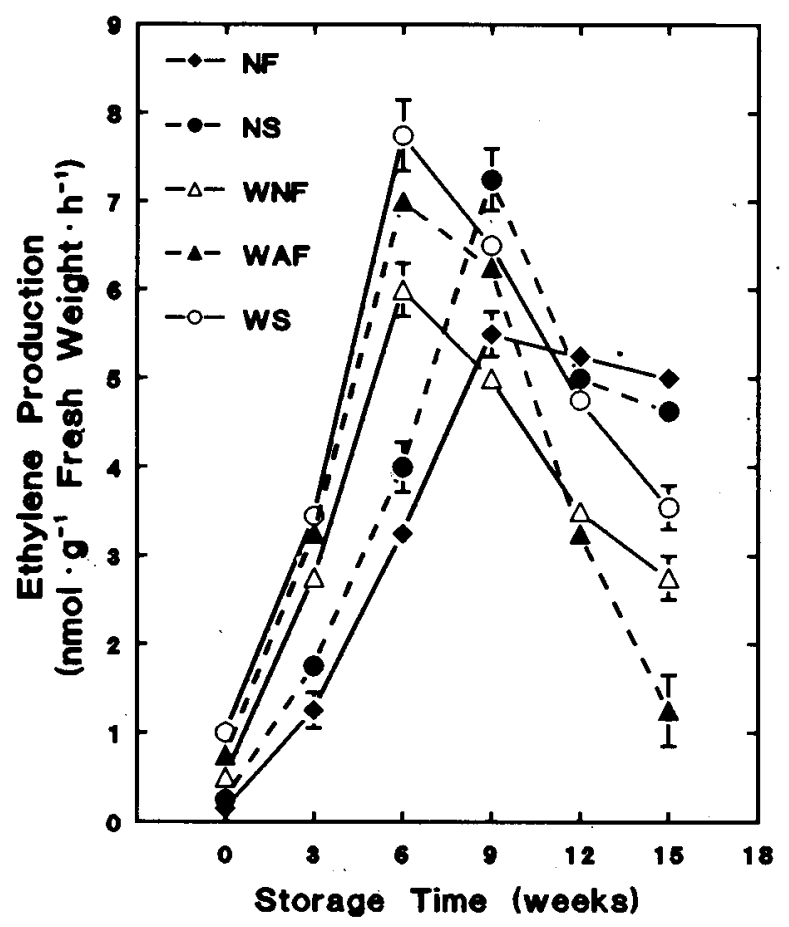

Fig. 2. Ethylene production from skin and flesh tissues of normal and watercore-affected 'Delicious' apples at harvest and periodically after removal from 0C storage. $\mathrm{NS}=$ normal skin; $\mathrm{NF}=$ normal flesh; WS = skin from apples with watercore; WNF = apples with watercore, nonaffected flesh; WAF $=$ apples with watercore, affected flesh. Vertical bars denote \pm SE, bars smaller than the symbols are not shown.

slices with or without watercore were used in this study. Skin and flesh from normal fruit, and skin, nonaffected flesh, and flesh affected from fruit with watercore were used for chemical analyses. Samples were taken at harvest and at 3-week intervals throughout 15 weeks of storage.

Ethylene determination. Ethylene production of whole affected and normal fruit was-determined by gas chromatography (GC) equipped with an alumina column and a flame ionization detector. Ten individual fruit were used for $\mathrm{C}_{2} \mathrm{H}_{4}$ assay at each sampling. Before making the $\mathrm{C}_{2} \mathrm{H}_{4}$ measurements, the fruit were warmed at $20 \mathrm{C}$ for 1 day after removal from $0 \mathrm{C}$.

Tissue disks at $10 \mathrm{~mm}$ diameter and 2-mm-thick flesh or 1mm-thick skin were cut from each of 10 fruit for each treatment. Tissue disks were washed in $600 \mathrm{~mm}$ sorbitol and $10 \mathrm{~mm}$ Mes [2-(N-Morpholino) ethanesulfonic acid] buffer ( $\mathrm{pH}$ 6.0). About $1 \mathrm{~g}$ of sample was placed in $25-\mathrm{ml}$ flasks containing $3 \mathrm{ml} 600$ mM sorbitol and $10 \mathrm{~mm}$ Mes buffer (pH 6.0) solution. Flasks were incubated in a 30C shaking water bath. After 3 to $4 \mathrm{~h}$, $\mathrm{C}_{2} \mathrm{H}_{4}$ in the headspace of the flask was determined by gas chromatography. Mature apple fruit already producing $\mathrm{C}_{2} \mathrm{H}_{4}$ do not form wound $\mathrm{C}_{2} \mathrm{H}_{4}$ upon slicing (Lieberman and Wang, 1982).

ACC synthase extraction and assay. ACC synthase was extracted as described by Bufler and Bangerth (1983). The extraction medium contained $100 \mathrm{~mm}$ Tricine- $\mathrm{KOH}(\mathrm{pH} 8.5), 4$ mM dithioerythritol (DTE), 5 Mm pyridoxal phosphate, and $0.2 \%$ (v/v) Triton X-100. One gram of lyophilized tissue was extracted with $10 \mathrm{ml}$ extraction medium using a cold mortar and pestle. The extract was first centrifuged for $15 \mathrm{~min}$ at $25,000 \mathrm{x}$ g. The pellet was then extracted with $5 \mathrm{ml}$ of extraction medium, centrifuged again as above, and the two supernatants combined. Two-milliliter samples of supernatant were purified on a Seph-

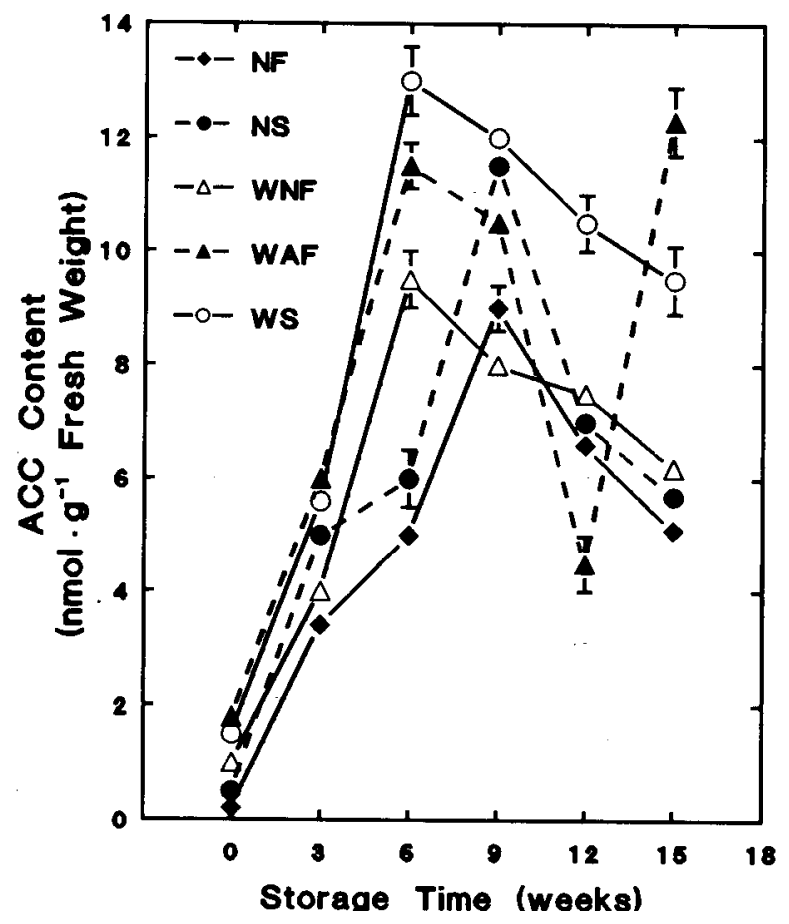

Fig. 3. ACC content from skin and flesh tissues of normal and watercore-affected 'Delicious' apples at harvest and periodically after removal from 0C storage. NS = normal skin; NF = normal flesh; $\mathrm{WS}=$ skin from apples with watercore; $\mathrm{WNF}=$ apples with watercore, nonaffected flesh; WAF $=$ apples with watercore, affected flesh. Vertical bars denote \pm SE, bars smaller than the symbols are not shown.

adex G-50 column (Pharmacia, Piscataway, N. J.) $(14$ x $1 \mathrm{~cm})$, previously equilibrated with $5 \mathrm{~mm}$ Tricine- $\mathrm{KOH}$ ( $\mathrm{pH} 3.0$ ), containing $0.1 \mathrm{~mm}$ DTE and $1 \mu \mathrm{M}$ pyridoxal phosphate. The protein fraction was collected and used in the enzyme assay. All steps were carried out at $4 \mathrm{C}$.

ACC synthase activity was determined according to Boiler et al. (1979). The reaction mixture contained $0.4 \mathrm{ml}$ enzyme, 50 mm Tricine- $\mathrm{KOH}(\mathrm{pH} \mathrm{8.0)}$, and $40 \mathrm{nmol}$ AdoMet in a total volume of $0.6 \mathrm{ml}$. After the reaction mixture had incubated for $1 \mathrm{~h}$ at $30 \mathrm{C}$, the ACC formed was assayed by the method of Lizada and Yang (1979).

Protein determination. Protein concentration was determined by the method of Bradford (1976).

Extraction of polyamines, AdoMet, ACC, and MACC. Two grams of tissue (fresh weight) were extracted one at a time, with $15 \mathrm{ml}$ of $5 \%$ ice-cold $\mathrm{HClO}_{4}$ for $1 \mathrm{~h}$. The extracts were centrifuged for $20 \mathrm{~min}$ at $5000 \times g$ and the supernatants were analyzed for ACC, MACC, AdoMet, and free polyamides.

Determination of polyamines. The supernatants from the $\mathrm{HClO}_{4}$ extracts were adjusted to $\mathrm{pH} 4.5$ at $0 \mathrm{C}$ with $\mathrm{KHCO}_{3}$ and then centrifuged at $4 \mathrm{C}, 6000 \times g$ for $20 \mathrm{~min}$. The supernatant $(\mathrm{pH}$ 4.5) was passed through a Bio-Rex 70 column ( $\mathrm{H}^{+}$form) that retained AdoMet and polyamides. AdoMet and polyamides were eluted from the Bio-Rex 70 column with $0.1 \mathrm{M} \mathrm{HCl}$ After neutralization, they were lyophilized and dissolved in $1.5 \mathrm{ml}$ $5 \% \mathrm{HClO}_{4}$, and used for free polyamine determination. Levels of polyamides were determined after dansylation (Wang and Steffens, 1985). The $10 \mu \mathrm{l}$ of dansylated products was then analyzed using high-pressure liquid chromatography by the methods of Kramer and Wang (1989).

Determination of total AdoMet. An aliquot of the Bio-Rex 


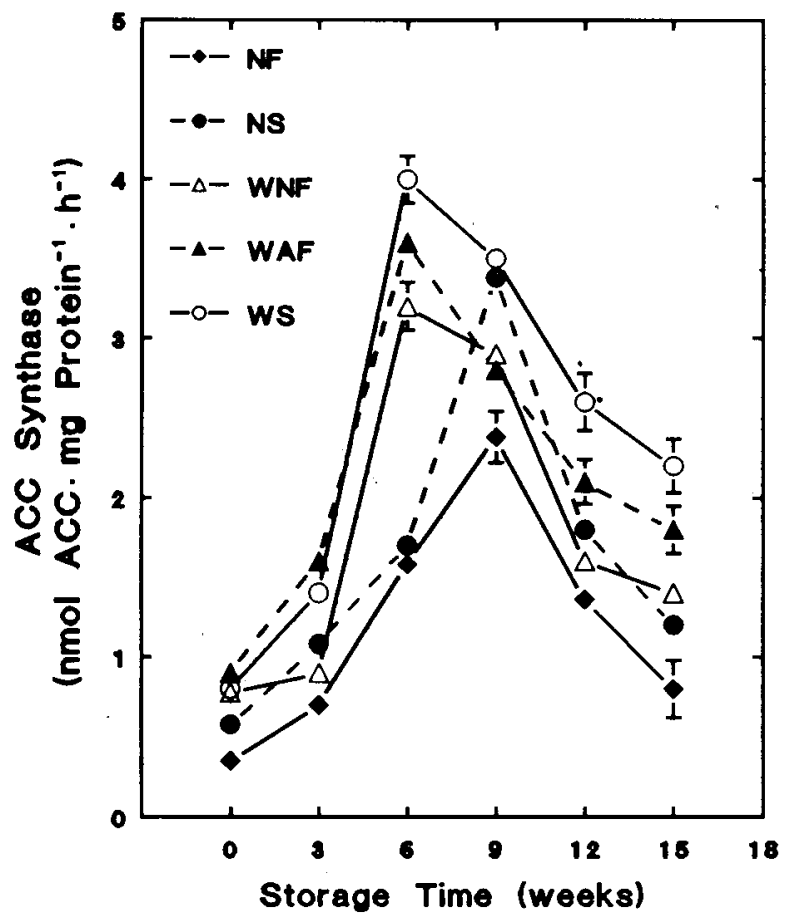

Fig.4. ACC synthase activity from skin and flesh tissues of normal and watercore-affected 'Delicious' apples at harvest and periodically after removal from 0C storage. $\mathrm{NS}=$ normal skin; $\mathrm{NF}=$ normal flesh; WS = skin from apples with watercore; WNF = apples with watercore, nonaffected flesh; WAF = apples with watercore, affected flesh. Vertical bars denote \pm SE bars smaller than the symbols are not shown.

70 fraction was chromatographed on prewashed Whatman 3 MM paper in $4 \mathrm{n}-\mathrm{BuOH}: 1 \mathrm{HOAc}: 5 \mathrm{H}_{2} \mathrm{O}$ (by volume) and the AdoMet spot was eluted with $\mathrm{H}_{2} \mathrm{O}$. The concentration of AdoMet was determined spectrophotometrically, assuming a molar absorptivity of 15,400 at $256 \mathrm{~nm}$ (Yu et al., 1980). Isotope dilution (Wang and Steffens, 1985) was also used to determine AdoMet concentration. The specific activity of the added 3,4${ }^{14} \mathrm{C}$-labeled AdoMet decreases as a result of dilution by endogenous AdoMet in the tissue extracts. By using ACC synthase, which catalyses the conversion of AdoMet to ACC, the amount of nonradioactive AdoMet in the tissue could be calculated from the specific radioactivity of ACC produced and the total radioactivity of AdoMet added. ACC synthase was isolated from apples as described above and ACC was assayed according to the method of Lizada and Yang (1979), which is based on the chemical conversion of ACC to $\mathrm{C}_{2} \mathrm{H}_{4}$ with $\mathrm{NaOCl}$. The $\mathrm{C}_{2} \mathrm{H}_{4}$ produced was then transferred to an evacuated $25-\mathrm{ml}$ scintillation vial. A 2-ml gas sample was withdrawn from the vial for $\mathrm{C}_{2} \mathrm{H}_{4}$, determination by GC. The remainder of the $\mathrm{C}_{2} \mathrm{H}_{4}$ was absorbed in $0.5 \mathrm{ml}$ of cold $0.25 \mathrm{M} \mathrm{Hg}\left(\mathrm{ClO}_{4}\right)_{2}$ for $3 \mathrm{~h}$. Then 10 $\mathrm{ml}$ of Aquasol scintillation fluid was added, and radioactivity was determined via a liquid scintillation counter ( $\mathrm{Yu}$ et al., 1980; Wang et al., 1982).

Determination of ACC and MACC. The material not retained by the Bio-Rex 70 column was passed through a Dowex-50 column $\left(\mathrm{H}^{+}\right.$form). Amino acids, including $\mathrm{ACC}$, were eluted with $3 \mathrm{M} \mathrm{NH}_{4} \mathrm{OH}$, and the eluate was taken to dryness; the residues were dissolved in $0.8 \mathrm{ml} \mathrm{H}_{2} \mathrm{O}$ and used for the ACC assay (Lizada and Yang, 1979). The effluent from the Dowex50 ( $\mathrm{H}^{+}$form) contained MACC. Quantification of the MACC was carried out by hydrolysis in $6 \mathrm{~m} \mathrm{HCl}$ at $100 \mathrm{C}$ for $1 \mathrm{~h}$, and the resulting ACC was assayed as described above.

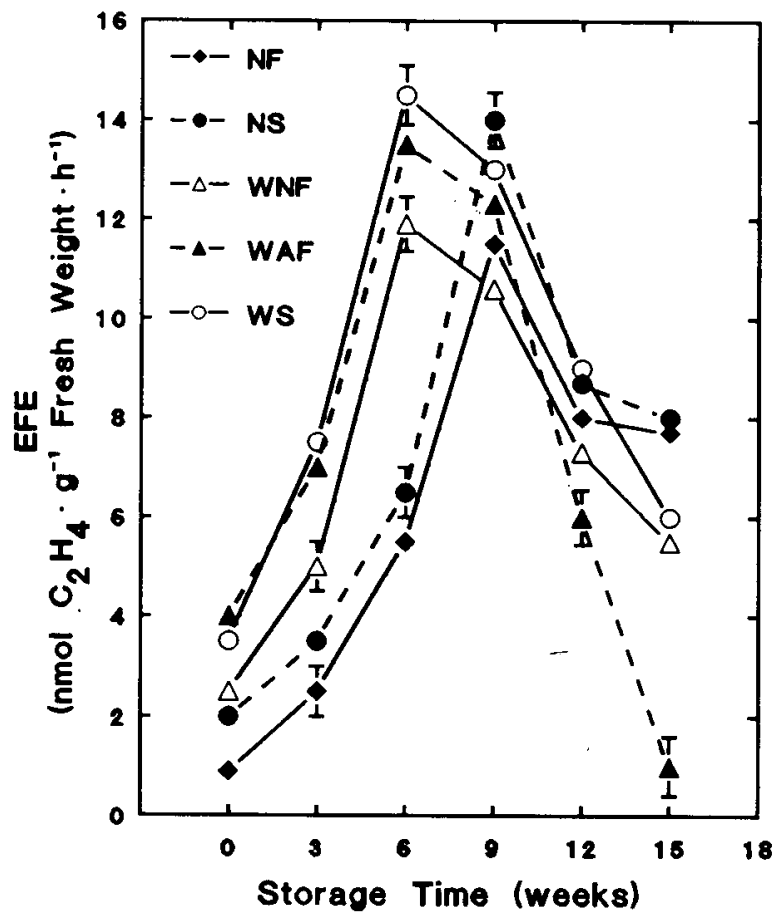

Fig. 5. EFE activity from skin and flesh tissues of normal and watercore-affected 'Delicious' apples at harvest and periodically after removal from 0C storage. NS = normal skin; NF = normal flesh; $\mathrm{WS}=$ skin from apples with watercore; $\mathrm{WNF}=$ apples with watercore, nonaffected flesh; WAF = apples with watercore, affected flesh. Vertical bars denote \pm SE, bars smaller than the symbols are not shown.

Ethylene-forming enzyme activity. One gram of flesh or skin tissues from watercore-affected or normal apples was incubated at $25 \mathrm{C}$ in a $25-\mathrm{ml}$ flask containing $3 \mathrm{ml}$ of incubation medium (600 mM sorbitol, $10 \mathrm{~mm}$ Mes buffer, $\mathrm{pH}$ 6.0) in the presence (EFE activity) or absence $\left(\mathrm{C}_{2} \mathrm{H}_{4}\right.$ production) of $1 \mathrm{~mm}$ ACC. Incubations were carried out $1 \mathrm{~h}$ after the tissues were cut to allow for the escape of internal $\mathrm{C}_{2} \mathrm{H}_{4}$. The flasks were then sealed with serum caps, and gas samples were taken after $3 \mathrm{~h}$ for $\mathrm{C}_{2} \mathrm{H}_{4}$ analysis by $\mathrm{GC}$.

\section{Results and Discussion}

Ethylene production, ACC and MACC content, ACC synthase, and EFE. Ethylene production of intact apples from midOctober to February indicated that the apples were in the preclimacteric stage at the start of these experiments (Fig. 1). With increased time in $0 \mathrm{C}$ storage, the apples showed the usual rise and fall of $\mathrm{C}_{2} \mathrm{H}_{4}$ production associated with the climacteric. Ethylene in unaffected fruit reached its peak $\approx 9$ weeks after harvest. In contrast, in apples with watercore $\mathrm{C}_{2} \mathrm{H}_{4}$ production peaked 6 weeks after harvest. The total production of $\mathrm{C}_{2} \mathrm{H}_{4}$ was slightly higher in affected than normal apples, but the rate of its increase was similar for the two groups of fruit (Fig. 1). Skin tissue produced more $\mathrm{C}_{2} \mathrm{H}_{4}$ than either affected or nonaffected flesh of watercore-affected apples (Fig. 2). Similarly, skin tissue produced more $\mathrm{C}_{2} \mathrm{H}_{4}$ than flesh tissue in normal apples. The rate of increase in $\mathrm{C}_{2} \mathrm{H}_{4}$ production and its peak time in each tissue was the same as in whole apples. The peak of $\mathrm{C}_{2} \mathrm{H}_{4}$ production in every tissue of affected apples occurred 6 weeks after harvest, while in normal apples the peak was 9 weeks after harvest. Each tissue of apples with watercore produced more total $\mathrm{C}_{2} \mathrm{H}_{4}$ than the corresponding tissue of normal fruit. After 


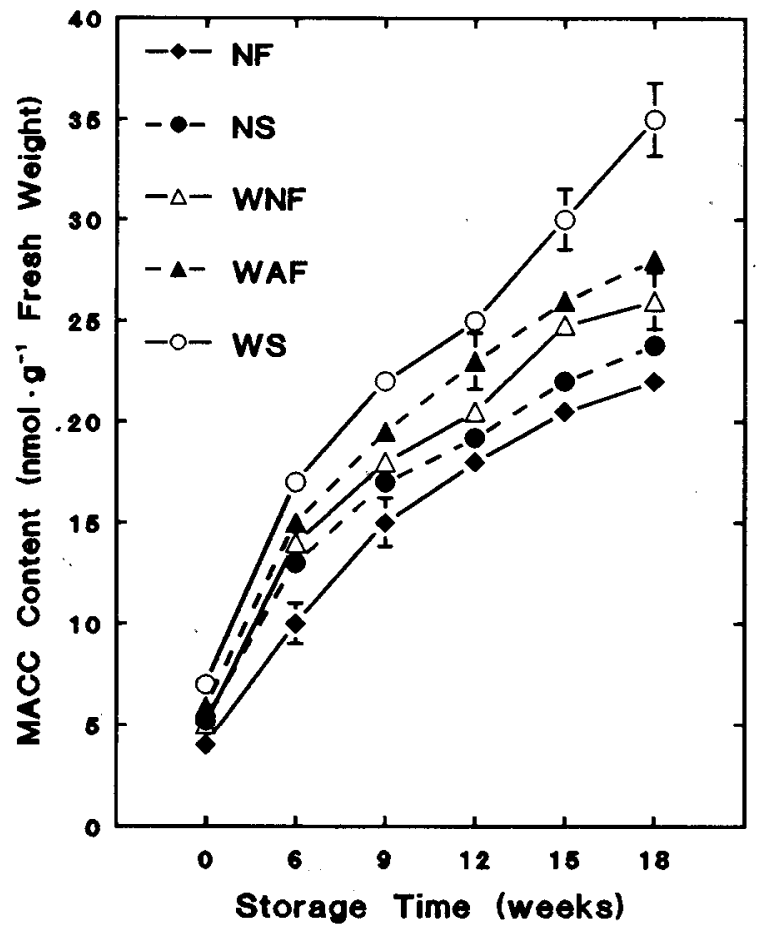

Fig. 6. MACC content from skin and flesh tissues of normal and watercore-affected 'Delicious' apples at harvest and periodically after removal from 0C storage. $\mathrm{NS}=$ normal skin; NF = normal flesh; $\mathrm{WS}=$ skin from apples with watercore; $\mathrm{WNF}=$ apples with watercore, nonaffected flesh; WAF = apples with watercore, affected flesh. Vertical bars denote $\pm \mathrm{SE}$, bars smaller than the symbols are not shown.

9 weeks of storage, $\mathrm{C}_{2} \mathrm{H}_{4}$ production declined rapidly, especially in the affected flesh of affected fruit. The earlier peak of $\mathrm{C}_{2} \mathrm{H}_{4}$ indicates that apples with watercore are more advanced physiologically than normal apples (Brooks and Fisher, 1926).

The ACC content, ACC synthase, and EFE activities of all tissues were very low at harvest (Figs. 3-5), limiting $\mathrm{C}_{2} \mathrm{H}_{4}$ production. It has been reported that preclimacteric fruit tissue lacks the capability not only for ACC synthesis but also for the conversion of ACC to $\mathrm{C}_{2} \mathrm{H}_{4}$ (Hoffman and Yang, 1980).

The concentration of MACC increased in parallel with the high rate of ACC synthesis. The skin contained higher amounts of ACC and MACC than the flesh (Figs. 3 and 6). The content of MACC in skin or flesh was considerably higher than that of free ACC. The MACC level in all tissues increased during storage and did not show the pattern displayed by all other components examined. In general, EFE activity followed the same pattern as ACC synthase and ACC content (Figs. 3-5). The reduced ACC levels in normal tissue during later periods of storage (12 to 15 weeks) might be due to the rapid and steady conversion of ACC to $\mathrm{C}_{2} \mathrm{H}_{4}$, as reported by others (Lau et al., 1984; Lipton and Wang, 1987; Wang et al., 1985). Tissue with watercore contained more ACC and MACC than did normal tissue. The activities of ACC synthase and EFE were also higher in affected than in normal apples. After 12 weeks of storage, EFE activity in watercore-affected flesh was drastically inhibited (Fig. 5), resulting in ACC accumulation and low $\mathrm{C}_{2} \mathrm{H}_{4}$ production (Figs. 2 and 3). The system converting ACC to $\mathrm{C}_{2} \mathrm{H}_{4}$ may have been damaged in watercore-affected flesh at this stage. Also, internal $\mathrm{O}_{2}$ concentration in watercore-affected tissue is low (Kato and Sate, 1978). Formation of $\mathrm{C}_{2} \mathrm{H}_{4}$ from ACC requires $\mathrm{O}_{2}$ (Adams and Yang, 1979). If $\mathrm{O}_{2}$ is limiting, conver-

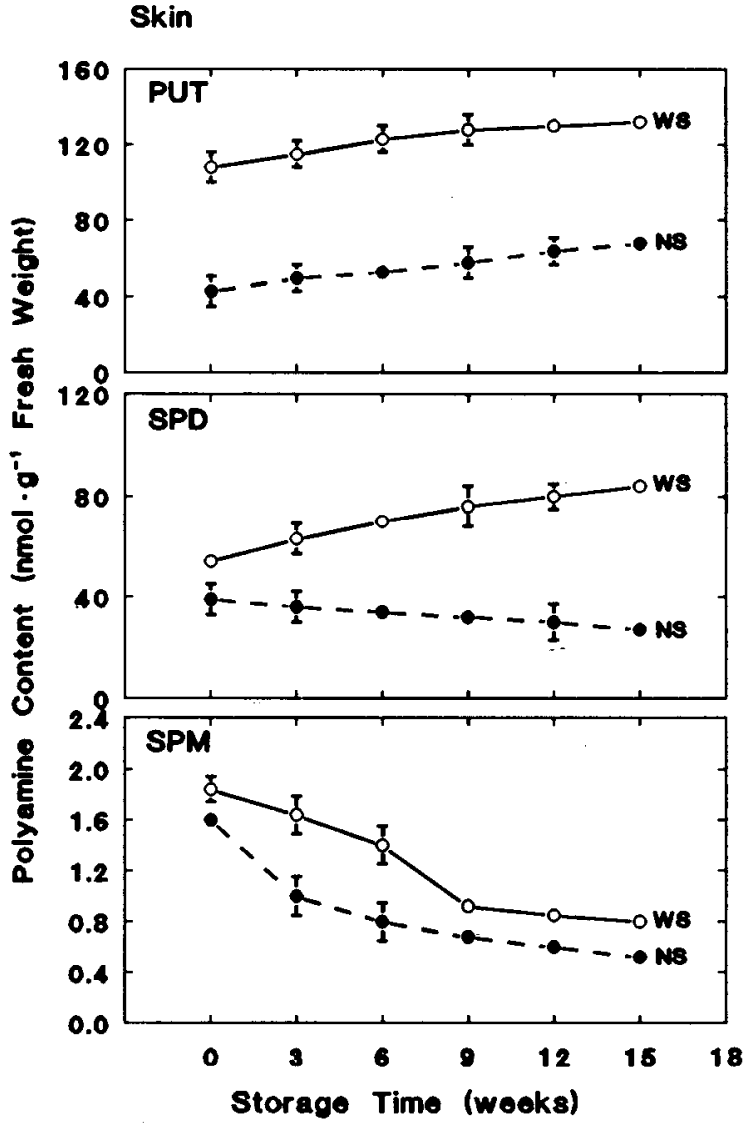

Fig. 7. Polyamine content of skin tissue from normal and watercoreaffected 'Delicious' apples at harvest and periodically after removal from $0 \mathrm{C}$ storage. $\mathrm{NS}=$ normal skin; $\mathrm{WS}=$ skin from apples with watercore. Vertical bars denote \pm SE, bars smaller than the symbols are not shown.

sion of ACC to $\mathrm{C}_{2} \mathrm{H}_{4}$ will be impaired and $\mathrm{ACC}$ accumulation and low $\mathrm{C}_{2} \mathrm{H}_{4}$ production are expected. EFE activity was not inhibited either in the skin or nonaffected flesh of fruit with watercore.

Polyamine content. In the skin of apples with watercore, PUT and SPD increased while SPM decreased with time in storage, but all remained higher than in normal apples (Fig. 7). Similar results were observed in the flesh (Fig. 8). Polyamine levels were generally lower in the flesh than in skin tissue. Affected flesh contained higher levels of polyamides than nonaffected flesh of affected apples, but both were higher than in the flesh of normal fruit. The greater accumulation of polyamides in watercore tissue is unexplained, but may be due to a higher amount of sorbitol in watercored apples (Williams, 1966). Flores and Galston (1984) have shown that a higher than normal concentration of sorbitol causes osmotic stress, which, in turn, increases PUT and SPD levels. Increases in polyamine levels in rice seedlings have also been shown under $\mathrm{O}_{2}$-deficit stress (Reggiani and Bertani, 1989; Reggiani et al., 1989). Since tissue of apples with watercore has a low $\mathrm{O}_{2}$ concentration (Kato and Sate, 1978), this may have also contributed to the higher content of polyamides in watercore-affected tissue.

AdoMet content. Fruit with watercore have higher ACC and polyamine contents than normal fruit. However, AdoMet levels in skin or flesh were the same for both types of fruit (data not shown). These data indicate that the step between methionine and AdoMet is not rate-limiting. No change in the level of 
Flesh

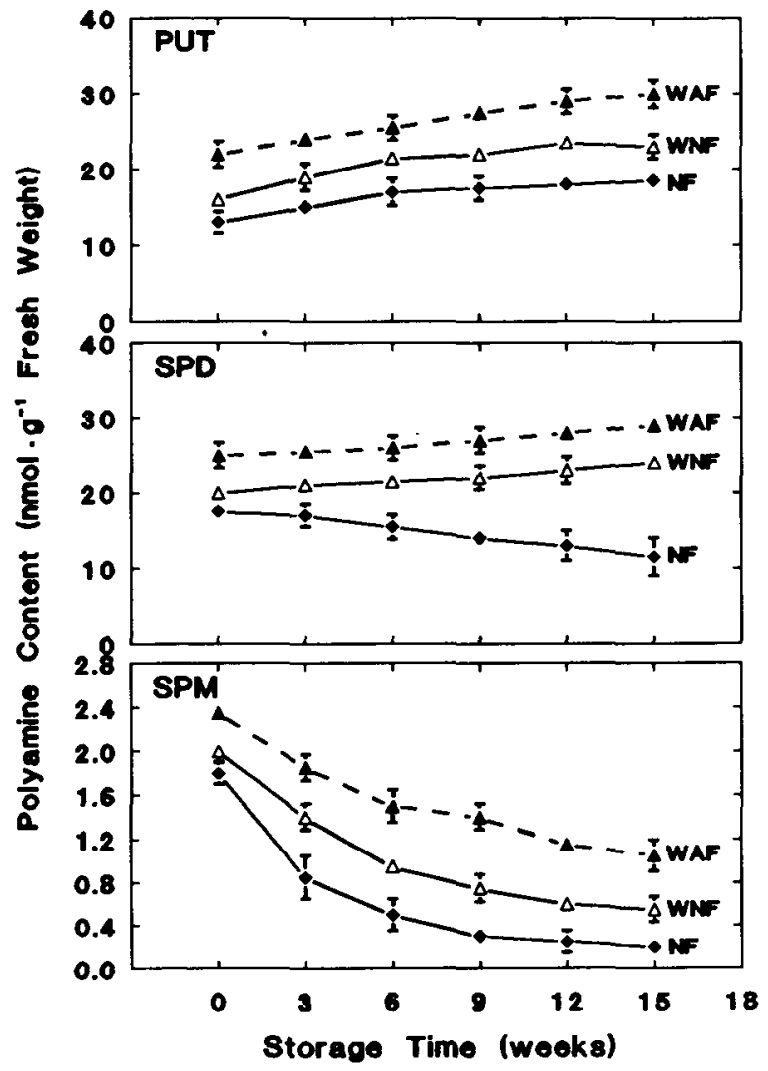

Fig. 8. Polyamine content of flesh tissue from normal and watercoreaffected 'Delicious' apples at harvest and periodically after removal from 0C storage. $\mathrm{NF}=$ normal flesh; $\mathrm{WNF}=$ apples with watercore, nonaffected flesh; WAF = apples with watercore, affected flesh. Vertical bars denote $\pm \mathrm{SE}$, bars smaller than the symbols are not shown.

AdoMet was observed even when $\mathrm{C}_{2} \mathrm{H}_{4}$ and the polyamides were actively synthesized. AdoMet is the substrate for both ACC and polyamine synthesis, but its consumption apparently did not alter the AdoMet steady-state level. Similar results were reported in water-stressed apple leaves (Wang and Steffens, 1985). Kushad et al. (1988) also demonstrated that the polyamine and $\mathrm{C}_{2} \mathrm{H}_{4}$ biosynthetic pathways are not actively competing for AdoMet at any given stage of avocado fruit development and ripening.

Collectively, the data presented here indicate that watercoreaffected fruit contains higher concentrations of PUT, SPD, ACC, and MACC and produces more $\mathrm{C}_{2} \mathrm{H}_{4}$ than normal fruit. The ACC synthase activity in affected fruit was also higher than in normal fruit, probably due to osmotic stress induced by the high sorbitol content in fruit with watercore. The EFE in severely watercore-affected flesh was inhibited, possibly due to low internal $\mathrm{O}_{2}$ levels that may result in ACC accumulation and low $\mathrm{C}_{2} \mathrm{H}_{4}$ production. No change in the level of AdoMet was observed between normal and watercore-affected fruits, although the polyamides and $\mathrm{C}_{2} \mathrm{H}_{4}$ were actively synthesized. Our results detail several metabolic aspects of watercore in apples-a complex disorder. Further research is needed to elucidate the interaction between polyamides, $\mathrm{C}_{2} \mathrm{H}_{4}$, sorbitol, and general metabolic state of the overmature apple fruit, as exemplified by watercoreaffected tissue.

\section{Literature Cited}

Adams, D.O. and S.F. Yang. 1977. Methionine metabolism in apple tissue: Implication of S-adenosylmethionine as an intermediate in the conversion of methionine to ethylene. Plant Physiol. 60:892896.

Adams, D.O. and S.F. Yang. 1979. Ethylene biosynthesis: Identification of 1-aminocyclopropane- 1-carboxylic acid as an intermediate in the conversion of methionine to ethylene. Proc. Natl. Acad. Sci. USA $76: 170-174$

Atkinson, J.D. 1971. Diseases of tree fruits in New Zealand. Dept. of Scientific and Ind. Res., Auckland, New Zealand.

Boiler, T., R.C. Hemer, and H. Kende. 1979. Assay for and enzymatic formation of an ethylene precursor, 1-aminocyclopropane-1-carboxylic acid. Planta 145:293-303.

Bradford, M.M. 1976. A rapid and sensitive method for the quantitation of microgram quantities of protein utilizing the principle of protein-dye binding. Anal. Biochem. 72:248-254.

Brooks, C. and D.F. Fisher. 1926. Water-core of apples. J. Agr. Res. 32:223-260.

Bufler, G. and F. Bangerth. 1983. Effects of propylene and oxygen on the ethylene-producing system of apples. Physiol. Plant. 58:486492.

Faust, M., C.B. Shear, and M.W. Williams. 1969. Disorders of carbohydrate metabolism of apples. Bet. Rev. 35:168-194.

Fisher, D.F. 1923. Watercore. Wash. State Hort. Proc. 19:98-104.

Flores, H.E. and A.W. Galston. 1984. Osmotic stress-induced polyamine accumulation in cereal leaves. Plant Physiol. 75:102-109.

Galston, A.W. 1983. Polyamides as modulator of plant development. Bioscience 33:382-388.

Hoffman, N.E. and S.F. Yang. 1980. Changes of 1-aminocyclopropane-1-carboxylic acid content in ripening fruits in relation to their ethylene production rates. J. Amer. Soc. Hort. Sci. 105:492-495.

Kate, K. and R. Sate. 1978. The ripening of apple fruits. II. Interrelations of respiration rate, $\mathrm{C}_{2} \mathrm{H}_{4}$ evolution rate and internal gas concentrations, and their relations to specific gravity of watercore during maturation and ripening. J. Jpn. Soc. Hort. Sci. 46:530-540.

Kramer, G.F. and C.Y. Wang. 1989. Correlation of reduced chilling injury with increased spermine and spermidine levels in zucchini squash. Physiol. Plant. 76:479-484.

Kushad, M.H., G. Yelenosky, and R. Knight. 1988. Interrelationship of polyamine and ethylene biosynthesis during avocado fruit development and ripening. Plant Physiol. 87:463-467.

Lau, O.L., Y. Liu; and S.F. Yang. 1984. Influence of storage atmospheres and procedures on 1-aminocyclopropane-1-carboxylic acid content in relation to flesh firmness in 'Golden Delicious' apples. HortScience 19:425-426.

Lau, O.L., Y. Liu, and S.F. Yang. 1986. Effects of fruit detachment on ethylene biosynthesis and loss of flesh firmness, skin color, and starch in ripening 'Golden Delicious' apple. J. Amer. Soc. Hort. Sci. 111:731-734.

Lieberman, M. and S.Y. Wang. 1982. Influence of calcium and magnesium on ethylene production by apple tissue slices. Plant Physiol. 69:1150-1155

Lipton, W.J. and C.Y. Wang. 1987. Chilling exposures and ethylene treatment change the level of ACC in 'Honey Dew' melons. J. Amer. Soc. Hort. Sci. 112:109-112.

Lizada, M.C.C. and S.F. Yang. 1979. A simple and sensitive assay for 1-aminocyclopropane-1-carboxylic acid. Anal. Biochem. 100:140145.

Marlow, G.C. and W.H. Loescher. 1984. WaterCore. Hort. Rev. 6:189251.

Olsen, K., H.A. Schemer, and G.S. Birth. 1962. Detection and evaluation of watercore in apples by light transmittance. Proc. Wash. State Hort. Assn. 58:195-197.

Reggiani, R. and A. Bertani. 1989. Effect of decreasing oxygen concentrations on polyamine metabolism in rice and wheat shoots. J. Plant Physiol. 135:375-377.

Reggiani, R., A. Hochkoeppler, and A. Bertani. 1989. Polyamides 
and anaerobic elongation of rice coleoptile. Plant Cell Physiol. 30:893898.

Wang, C. Y., C.E. Sams, and K.C. Gross. 1985. Ethylene, ACC, soluble polyuronide, and cell wall noncellulosic neutral sugar content in 'Eldorado' pears during cold storage and ripening. J. Amer. Sot. Hort. Sci. 110:687-691.

Wang, S.Y., D.O. Adams, and M. Lieberman. 1982. Recycling of 5 '-methylthioadenosine ribose carbon into methionine in tomato tissue in relation to ethylene production. Plant Physiol. 70:117-121.

Wang, S.Y. and G.L. Steffens. 1985. Effect of paclobutrazol on water stress-induced ethylene biosynthesis and polyamine accumulation in apple seedling leaves. Photochemistry 24:2185-2190.

Wang, S. Y., P. Wang, and M. Faust. 1988. Non-destructive detection of watercore in apple with nuclear magnetic resonance imaging. Scientia Hort. 35:227-234.

Williams, M.W. 1966. Relationship of sugars and sorbitol to watercore in apples. Proc. Amer. Soc. Hort. Sci. 88:67-75.

Yang, S.F. and N.E. Hoffman. 1984. Ethylene biosynthesis and its regulation in higher plants. Annu. Rev. Plant Physiol. 35:155-189.

Yu, Y. B., D.O. Adams, and S.F. Yang. 1980. Inhibition of ethylene production by 2,4-dinitrophenol and high temperature. Plant Physiol. 66:286-290. 